Article

\title{
The Romanian Family Businesses Philosophy for Performance and Sustainability
}

\author{
Camelia-Daniela Hategan ${ }^{1, *} \mathbb{0}$, Ruxandra-Ioana Curea-Pitorac ${ }^{2} \mathbb{C}$ and Vasile-Petru Hategan ${ }^{3}$ \\ 1 Department of Accounting and Audit, Faculty of Economics and Business Administration, West University \\ of Timisoara, 16 Pestalozzi Street, 300115 Timisoara, Romania \\ 2 Department of Economics and Modeling, Faculty of Economics and Business Administration, West \\ University of Timisoara, 16 Pestalozzi Street, 300115 Timisoara, Romania; ruxandra.curea@e-uvt.ro \\ 3 Institute for Social and Political Research, Faculty of Political Sciences, Philosophy and Communication \\ Studies, West University of Timisoara, 4 V. Parvan Blvd, 300223 Timisoara, Romania; vasile.hategan@e-uvt.ro \\ * Correspondence: camelia.hategan@e-uvt.ro; Tel.: +40-256-592-553
}

Received: 20 February 2019; Accepted: 10 March 2019; Published: 21 March 2019

check for updates

\begin{abstract}
Family businesses represent a large segment of private companies and contribute greatly to economic growth. In this context, the objectives of this paper are to identify the characteristics of Romanian family businesses, starting from their involvement and governance mechanisms, and also to investigate if these specific items allow them to act towards creating sustainable businesses. In order to achieve these objectives, we have used qualitative and quantitative research, consisting of two phases: (a) we have analyzed the reports regarding the Romanian family businesses, in order to identify their characteristics; and (b) we have empirically tested if the characteristics are correlated with company financial performance and social responsibility. The results show that Romanian family businesses are aware of the changes that may appear and that they have started to implement internal processes oriented towards sustainability. Also, the main family involvements in business were ownership, governance, management and succession, which have a correlation with the performance of their company.
\end{abstract}

Keywords: family business; philosophy; sustainability; performance; ownership; governance; management; succession

\section{Introduction}

Family businesses (FB) are an important segment of any economy and the way they manage their capabilities in order to adapt to changes and to create competitive advantage represents a particular challenge. According to some unofficial data (in the absence of official data) over 65\% of Romanian companies are family businesses [1]. In Romania, they have learned sailing into troubled waters and have also started adopting a long-term view, the needs for innovation and professionalism becoming the central concerns of these businesses.

In this context, our paper aims to investigate the characteristics of Romanian family businesses and of their governance mechanisms, and also to analyze if these specific items are correlated with company financial performance and social responsibility. We chose Romania for this study because the experience of family businesses is a relatively recent one, and the first businesses of the kind were developed after 1990. Family businesses are not analyzed or included in Romania's official statistics, being classified as small and medium enterprises (SMEs). Moreover, even if their number is quite high, few of them have succeeded in adapting to the changes occurring in recent years and also to develop. Now, 29 years after the beginning of the first family businesses, they face first generation change; the proportions of this change being hard to anticipate. 
Derived from philosophy, the concept of a company's philosophy manifests itself in practice in that business as the mission statement of the company, and it can be expressed under various names, including company mission, the firm's strategy, the firm's belief, the charter of values or even the philosophy of the company. All of these forms of writing a business statement are part of the philosophy applied in business, seen by some practitioners as a profession dedicated to the business environment, manifesting in the form of a philosophical business consultancy [2] with a profound interdisciplinary character that takes place between philosophical practice and business, manifesting itself more recently in the form of applied philosophical counseling in this field [3]. The family business challenges are multiple, including the dilemma of the owners about what should come first, family or business [4].

In many papers, the question arises as to whether family businesses perform better [5] and most of the responses are positive because the factors that influence performance are a result of family members' involvement [6]. Other topics of research were the succession of family business, the involvement of new generation and succession planning $[7,8]$. Also, another major challenge of family business is recruiting staff, retaining valuable employees [9] and professionalization of company for sustainable business $[10,11]$.

Family businesses from Europe contribute in a proportion of about $50 \%$ at the Gross Domestic Product [12] and better performance of family businesses is considered the key to economic and sustainable development [13]. Given their importance, family businesses have been organized in several associations, one of the most important in Europe is European Family Businesses (EFB). The Family Business Network Romania (FBNR), which currently has 25 members, has joined EFB [14].

Research on Romanian family businesses is scarce and focused on innovation and change management [15]; entrepreneurial learning processes [16]; perceptions of Romanian consumers regarding the phrase "family firm" [17]; the relationship between ownership and performance [18] in comparison with family business from Germany. The main conclusions were that Romania doesn't have a relevant tradition and the economic environment influenced the performance of family businesses.

In order to achieve the objectives of the paper, we performed a descriptive analysis and an econometric model. In the first phase, we have analyzed the reports of professional services companies regarding the situation of the Romanian family businesses, in order to identify their characteristics, the particularities of their organizational culture, their preoccupations for creating value, and so on. Starting from these conclusions, in the second phase we empirically tested the relationship between the performance of Romanian family businesses and their characteristics: ownership, governance, management and succession.

The research in this field base on Romanian companies has been scarce; this paper will contribute to developing the literature and can offer to members of family business opportunity to reflect, compare and identify new ways of business development on long term. Also, the present paper contributes to the literature for other reasons. First, it provides an extensive analysis of the available data regarding the status of Romanian family businesses from a perspective oriented towards the possibility of creating sustainable business. Secondly, it offers some insights into a relatively new type of business in Romania, meaning that the results could be extrapolated to other countries, especially to emerging countries, which more or less face a similar situations.

The paper is structured as follows. The next section contains a brief review of the specific literature regarding family businesses, while the third section presents the research hypotheses and describes the research methodology. The fourth section presents the results of the study' along with our comments. The last section includes some final remarks and conclusions.

\section{Literature Review}

As several authors note [19-21], a family business is a company characterized by the founder's or his family's involvement in aspects such as owning shares, the company's management, or work along the other family members. In the socio-economic environment, there is heterogeneity in what 
constitutes the definition of family business. A study performed for the European Commission [22] notices that "there does not exist a common, widespread definition or understanding of what constitutes a "family business" that is generally applied across Europe for political, economic as well as academic purposes at the same time". The Romanian law [23] defines family businesses as "the economic entity, without juridical personality, organized by an entrepreneur along with his family"; as enterprises established at the initiative of an individual and comprising his/her family members (husband, wife, children over 16 years, as well as their relatives, including the fourth-degree ones). It is one of the few family business definitions available using the term "family".

Defining family business is a very challenging issue. Shanker and Astrachan [24] classified definitions by degree of family involvement, on three levels from "broad (little direct family involvement), to middle (some family involvement), to narrow (a lot of family involvement)". In the vision of Astrachan et al [25] there are "three important dimensions of family influence that should be considered: power, experience, and culture" which comprise "the F-PEC, an index of family influence".

In ancient times, the first philosophical approaches to family business are noted in Plato's Republic [26], where the crafts are presented as a human activity that generates property that we know to have been transmitted in history, primarily to the family, as an important prerequisite for family businesses currently manifested. Politics of Aristotle [27] brings to the attention of philosophers of the times the concept of property that implicitly generates the concept of wealth. Aristotle being the adept of the middle-class government, thus arriving with another alternative to the society described by Plato, proposing another form of social ordering, based on property owned by people. Family business has a special feature, being taken over by the family descendants who continue the business like the social contract described by Jean-Jacques Rousseau [28], who says that it is permanently renewed by the participants.

Although family businesses have some certain advantages (solidarity inside the company, the speed of decision-making and actions, mutual trust, control of their own actions, the involvement of more generations etc.), they are confronted with specific problems, especially regarding governance. Miller and LeBreton-Miller [29] assert that governance in family businesses implies four crucial elements: family ownership and control, family management, multiple families and managers, and family succession, and they identify for each of these the positive and the negative aspects, as well as their effects on the performance of the company.

Besides, the connection between the governance of family businesses and their performance is the subject of several studies in the literature [29-31]. The manner in which businesses are run directly influences their performance. Because of this, they will seek to capitalize as well as possible on the resources available. Thus, they might consider the opportunity of alienating their shares or the company's management to persons outside the family. But, with the transfer of control towards other persons, there is the risk that the motivation of the family members and of the employees will decrease. In addition, the fact that family members own the majority of the shares could leave the interests of minority shareholders unprotected [29].

The literature proposes two approaches with regard to the corporate governance issue-agency theory and stewardship theory. The agency theory seeks to solve the problems of the relation between principals (owners) and agents (managers) [32-34] states that the agent's problem comes from the principals' and the agents' different motivations. The problems could appear as a result of the existence of some contrary interests on behalf of the two, as well as a result of their different attitudes towards risk [34-36]. In this context, they will be tempted to act pursuing different directions. Within family businesses, the coherence between the owner's interests and those of the manager may substantially reduce agency costs [36]. The affiliation to the same family assumes a long-term commitment supported by common interests and mutual trust and oriented towards the welfare of business, efficient management and the appropriate allocation of resources.

However, Chang et al. [37] point to the fact that management of a company by the members of a single family can be extremely dangerous if not properly restricted, because the management actions 
might become neglectful, risky or insensitive to the expectations of the minority shareholders. The identification of a proper governance mechanism is the key to solving the agency issue, by reducing the associated cost and raising the efficiency of the company.

On the other hand, the stewardship theory [38,39] assumes that, unlike the agency theory, managers are strongly motivated by the alignment to the owner's interests and not just pursuing their own interests. Thus, they will act for the organization's and shareholder's benefit [38-40]. Moreover, Davis et al. [39] state that this kind of attitude manifests itself through altruism, care for the shareholder's interests, conscientiousness, trust and commitment to the organization. In this context, the managers consider that their interests could be satisfied by directing their efforts towards satisfying the interests of the organization [37]. It is an intrinsic motivation for the collective welfare [29]. Such an approach is more prevalent within family businesses, because of the emotional relationships between the members, which results in total commitment towards the mission of the organization. In the long term, this approach contributes to the development of their own capabilities, which will secure them a sustainable competitive advantage, as well as financial returns.

In the case of family businesses, along with the theories mentioned, the socioemotional wealth theory (SEW) is also applied, which we can say has its origins in Hegel's theories. If Hegel [41] remarked that ever since the legal character of a person in the family appeared, when wealth is managed, that character has been transposed into the business developed by family members, which operate on the same principles of law as applied in the process of managing a common property, in a family business, identic to the group wealth of a family. It was observed that the specific character of a legal entity is also preserved in the management of a family business, which has the same objectives as the management of family wealth, only those involved are different.

SEW theory was developed by Gomez-Mejia et al. [42] whose definition is "non-financial aspects of the firm that meet the family's affective needs, such as identity, the ability to exercise family influence, and the perpetuation of the family dynasty". Berrone et al. [43] continued the research and found that SEW is based on five different dimensions: "(1) Family control and influence; (2) identification of family members with the firm; (3) Binding social ties; (4) Emotional attachment; and (5) Renewal of family bonds to the firm through dynastic succession" (acronym FIBER). Recent studies draw on the socioemotional wealth framework, which effectively points out family firms' motivations and agency conflict peculiarities [44,45].

Sustainability is the key challenge for a family business, the family involvement in a company bring mostly done through ownership and management [6]. Stafford et al [46] created the "Sustainable Family Business Model" to show that the company's durability is given by the models of relationship between the business and the family. They have proposed a model with two subsystems: family and business, which mutually working together to ensure the sustainability of family business. Núñez-Cacho et al. [47] developed the model by including a third subsystem, the community. They analyzed the three dimensions of a large Spanish company (Mercadona) and found that the community can influence business by disruption, and the family must respond to these threats to reputation and continuity. The study shows the transition to circular economy that can be applied to family businesses.

Oudah [48] conducted an analytic hierarchy process model created on the basis of factors influencing the survival of family businesses in the United Arab Emirates (UAE) and found that "they need to create and give more importance to succession planning, strategic planning and corporate governance to ensure their business longevity".

The relationship between family involvement and performance was studied in previous research [49-52], where the involvement was measured by four components: ownership, governance, management and succession. Garcia-Castro and Aguilera [53] presented a review of the literature with these studies structured on positive, negative and mixed/neutral relationships and the variables used in the models.

The business is considered "family" if one group of the family members owned the business, so ownership structure is an indicator taken into account in empirical studies. Block [54] studied the 
largest 500 family companies from the Global Family Business Index to analyze the differences between family management and family ownership and found that management moderate the relationship between performance and the value of the companies and owners are more preocuped about their reputation for social responsibility. Anderson and Reebe [55] have found that firms that have a family member as a CEO have a better performance than those with a CEO outside of the family.

Involvement of family members in governance is done through institutions, but also through adopted documents, the most common being the code of governance, the situation varies from one country to another [22]. According to Carney and Gedajlovic [56], the governance of a company determines the nature and the value of the resources it can secure, setting the assets, the activities and the capabilities which can be developed by the company.

The management of any business, including family businesses, must allow making decisions which secure the resource allocation and the involvement of their distinctive capabilities in activities which allow them to gain an advantage against competitors [57]. Barney [58] noted that these capabilities must be valuable, rare and hard to imitate or replace. The influence of the family in running the business is extremely important. Studies have been performed in order to establish if the family factor is an asset or a liability [59]. In this context, they state that in the conditions of a dynamic environment "the results show that the percentage of family members on the top management team has an inverted U-shaped relationship with firm performance".

In order to influence the performance of the family business, family members need to have control over it. Previous studies conducted on family businesses in various European countries confirm this, so Maury [60] in a study on 1672 companies from 13 countries in Western Europe for the year 1998 found that family control was correlated with better profitability. Barontini and Caprio [61] have identified a positive relationship between family control and firm performance on a sample of 675 companies from 11 countries in Continental Europe for the period 1999-2001. Sacristán-Navarro [62], using a sample of 118 nonfinancial Spanish listed companies from 2002 to 2008, found that family control is more important than ownership. Sciascia and Mazzola [63] have found no significant link between family involvement in ownership and performance for Italian family non-listed companies and Garcia-Ramos [64], based on a sample of European listed family companies, have found that the presence of a founder influences the performance of companies.

Some researchers have analyzed the performance differences between family businesses and non-family. Miralles [65] studied a sample of listed companies in Spain and Portugal between 1999 and 2008 and found that managers of family businesses influenced financial performance. Vieira's study [66] on a sample of 58 companies in Portugal listed during 1999-2010 showed that family-listed business shares perform better than non-family businesses.

Studies on family business in Central-Eastern Europe (CEE) are rather limited, a sample of 217 family companies in Poland (the biggest country from CEE), for the period from 1997 to 2005 were studied by Kowalewski et al [67], who have found an U-shaped relationship between the share of family ownership and the performance of the company, and firms with family executives may exceed the performance of the other companies.

In past years, the companies have understood that for their long-term sustainability they need to be involved in Corporate Social Responsibility (CSR) activities. Even if many family businesses do not have an extended corporate governance structure, most family members have decided to be socially responsible. The relationship between CSR and family firms was studied in many research papers, and the results were heterogeneous [68] and highly segmented and unstructured [69].

For the survival of a family business, they need to secure a new generation of leadership, and management accounting plays an important role by teaching young generations the internal control procedures [70] and the succession process [71]. For efficient management, any company relies on accountants and auditors. Researchers on the accounting of family businesses question whether there are differences and difficulties in financial reporting in family businesses. Prencipe et al [72] have reviewed the literature on a set of 37 published papers that explicitly examine accounting and reporting 
issues in family companies on the following topics: financial accounting and reporting; management accounting and control; and auditing of financial statements. The results of the study were that most of them relied on agency theory, and from an empirical point of view approaches were based on the heterogeneous definitions of family businesses, but in most of them, family involvement in the business was taken into account.

\section{Materials and Methods}

\subsection{The Model}

After a thorough review of the specific literature, we formulated the following research questions (Figure 1):

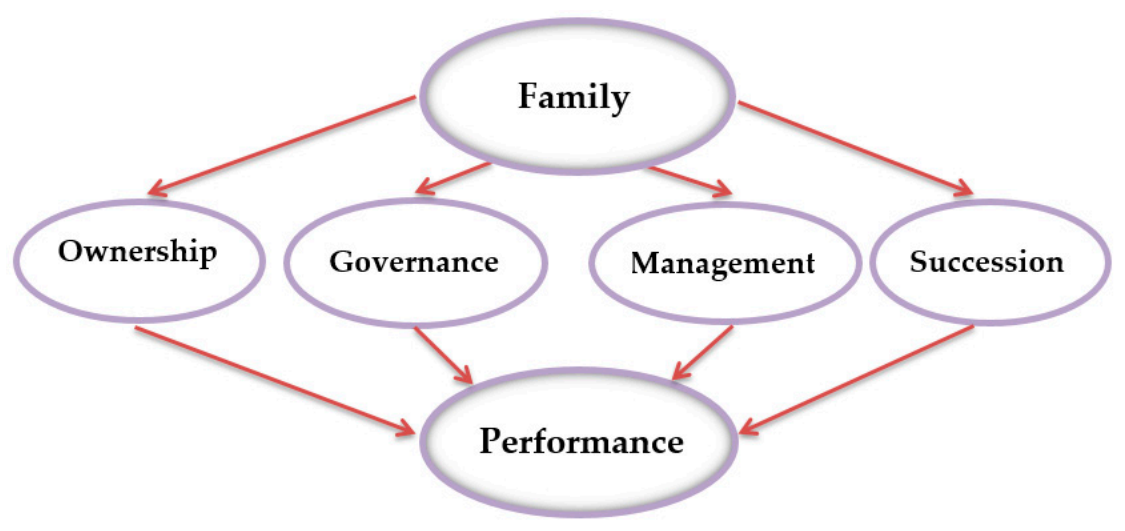

Figure 1. Research design.

RQ1: Which are the characteristics of the Romanian family businesses? Do they differ significantly from the characteristics identified at European and global level?

RQ2: Are the characteristics of Romanian family businesses correlated with the company performance (financial and non-financial)?

In order to answer these questions, we have employed qualitative and quantitative research consisting of two phases. In the first phase, we have analyzed several reports regarding the current situation of Romanian family businesses, with the purpose of identifying their characteristics, their preferred form of governance, the features of their organizational culture, their preoccupations for value creation, and so on.

We have analyzed the surveys issued by three consulting companies from the Big Four group which have specialized departments for family business consultancy and conduct annual research on this issue, covering the period 2016-2017. Ernst \& Young have published the family businesses barometer in Romania [73] and PricewaterhouseCoopers (PwC) performed Global Family Business Survey 2016/2017 [74] on the situation of the family businesses in Romania about entrepreneurship strategy and succession planning. The survey published by KPMG, which we used in our study, refers to the family businesses within the European Union (EU) [75]. The surveys mentioned above have been made on specific samples for each study, in which Romania was also included.

Starting from the conclusions drawn in the first phase, in the second one, we tested the following model:

$$
\begin{gathered}
\text { Company_Performance }_{i t}=\alpha+\beta_{1} \text { Ownershi }_{i t}+\beta_{2} \text { Governance }_{i t}+\beta_{3} \text { Management }_{i t}+ \\
\beta_{4} \text { Succesion }_{i t}+\beta_{5} \text { DebtRatio }_{i t}+\beta_{6} \text { Age }_{i t}+\beta_{6} \text { Size }_{i t}+\beta_{6} \text { Ind }_{i t}+\varepsilon_{i t}
\end{gathered}
$$

Our models had as the dependent variables the companies' performance indicators, the characteristics of the family businesses were the independent variables [53], and we also included four control variables to reduce the risk of biases and control for reliability. 
Company performance can be measured by financial and non-financial indicators. Regarding the empirical results, in previous family business studies $[53,76]$ for financial performance the most used indicators were return on equity (ROE), return on assets (ROA) and profit margin (PM), which is based on the company's annual earnings. However, the following indicators are also relevant for analyzing how to use assets: debt ratio and turnover total assets ratio (TAT), as indicators that help to interpret the company's evolution $[77,78]$.

Besides the financial reports, the companies can write, or they are required to write, non-financial reports, which helps to complete the image of the company. In this study, we have taken into account the companies' implication in social responsibility, action expressed through charitable contributions. This indicator was chosen because it was the only variable for which data were available for all companies in the sample, which may be relevant, based on previous research $[79,80]$.

For independent variables, the scale of measurement is the percentage of family members in ownership, governance and management $[29,53,63,81,82]$. For variable succession there was no clear data to measure it the same as the other three variables and was chosen a dummy variable, if the next generation is involved in ownership, governance or management or not.

Among the control variables included in the model, in accordance with previous studies $[53,81,83]$, were the firm-level characteristics (age and size), debt ratio [84] and industry affecting the financial performance.

All the indicators used in the model are presented in Table 1.

Table 1. Specifications on the model variables.

\begin{tabular}{|c|c|c|}
\hline Variable & Code & Description \\
\hline \multicolumn{3}{|l|}{ Dependent Variables (DV) } \\
\hline \multicolumn{3}{|l|}{ Financial Indicators } \\
\hline Return on Assets & ROA & Net profit/Total assets \\
\hline Return on Equity & ROE & Net profit/Equity \\
\hline Profit margin & PM & Net profit/Turnover \\
\hline Turnover total assets ratio & TAT & Turnover/Total assets \\
\hline \multicolumn{3}{|l|}{ Non-financial indicator } \\
\hline Social responsibility & SR & $\begin{array}{l}\text { Dummy variable taking value " } 1 \text { " if the company } \\
\text { is involved in social responsibility activities, } \\
\text { otherwise taking value " } 0 \text { " }\end{array}$ \\
\hline \multicolumn{3}{|l|}{ Independent Variables (IV) } \\
\hline Ownership & $\mathrm{O}$ & Percentage of share owned by family members \\
\hline Governance & G & $\begin{array}{l}\text { Percentage of family members in total number of } \\
\text { Supervisory Board }\end{array}$ \\
\hline Management & M & $\begin{array}{l}\text { Percentage of family members in total members in } \\
\text { board of directors (executive) }\end{array}$ \\
\hline Succession & S & $\begin{array}{l}\text { Dummy variable taking value " } 1 \text { " if the next } \\
\text { generation is involved in ownership, governance or } \\
\text { management, otherwise taking value " } 0 \text { " }\end{array}$ \\
\hline \multicolumn{3}{|l|}{ Control Variables (CV) } \\
\hline Debt ratio & DR & Total liabilities/Total assets \\
\hline Size & Size & total assets expressed in natural logarithm \\
\hline Age & Age & Number of activity years \\
\hline Industry & Ind & $\begin{array}{l}\text { NACE Rev. } 2 \text {-Statistical classification of economic } \\
\text { activities-2 digits }\end{array}$ \\
\hline
\end{tabular}

In order to determine the proper type of regression to be used, we first applied the Harris-Tzavalis test to check for stationarity. After, we performed an ordinary least square (OLS) regression; we used variance inflation factor (VIF) to test for multicoliniarity and Breusch-Pagan to test for heteroscedasticity. We applied the Hausman test to ascertain if we had endogenous regressors and to choose between fixed effects or a random effects model, the Pesaran CD test to check for cross-sectional dependence and the Wooldridge test to verify if there was a first-order autocorrelation in the panel data. After all the tests were performed, we decided to use Prais-Winsten correlated panels corrected standard errors regression (PCSEs), for the equation with financial indicators, and for the non-financial indicator we used 
a mixed-effects logistic regression. To study the explanatory power of the variables, first we tested the model using all the independent variables and afterwards we took into account only one at a time.

\subsection{Sample}

In the absence of official data, we selected active companies at 31st December 2017, with a turnover higher than 46 million ron (approx. 10 million euro), that have been active for more than 20 years, had 50 employees minimum, recorded a profit and had been owned by Romanian residents. Data was collected from a private database [85], which compiles official data. There were a total of 458 companies, from which were eliminated the state-owned companies, the ones that recorded losses during the period analyzed, the ones that were owned by persons not belonging to the same family, as well as those owned by other companies whose associates did not belong to the same families. After the elimination process, 163 companies remained in the sample, to which we added 16 companies that had family ties with associates from previously selected companies, and another 22, which are members of FBNR, even if they don't meet all the above mentioned criteria, we consider them to be relevant to our study, because they have publicly declared themselves (on their own websites, in financial newspapers, etc.) as a family business.

To check the reliability of data from the database we compared the results with the information from the website of The Ministry of Public Finance of Romania and from The National Trade Register Office.

Thus, our sample consisted of 201 Romanian companies with majority ownership in the same family, whose members are also involved in governance and management. Based on previous research $[62,66,67]$, the sample can be considered representative, the companies operate in all the development regions of Romania and in most important activity sectors. In Table 2 are presented the characteristics of the sample by activities, number of employees and turnover. The most companies were in the wholesale sector (38.31\%) followed by manufacturing (27.86\%) and retail (9.95\%). Two thirds of companies are small and medium enterprises (SMEs) that have less than 250 employees and only $14 \%$ had a turnover of less than 10 million euro (almost half of the companies are members FBNR).

Table 2. Characteristics of sample at 31 December 2017.

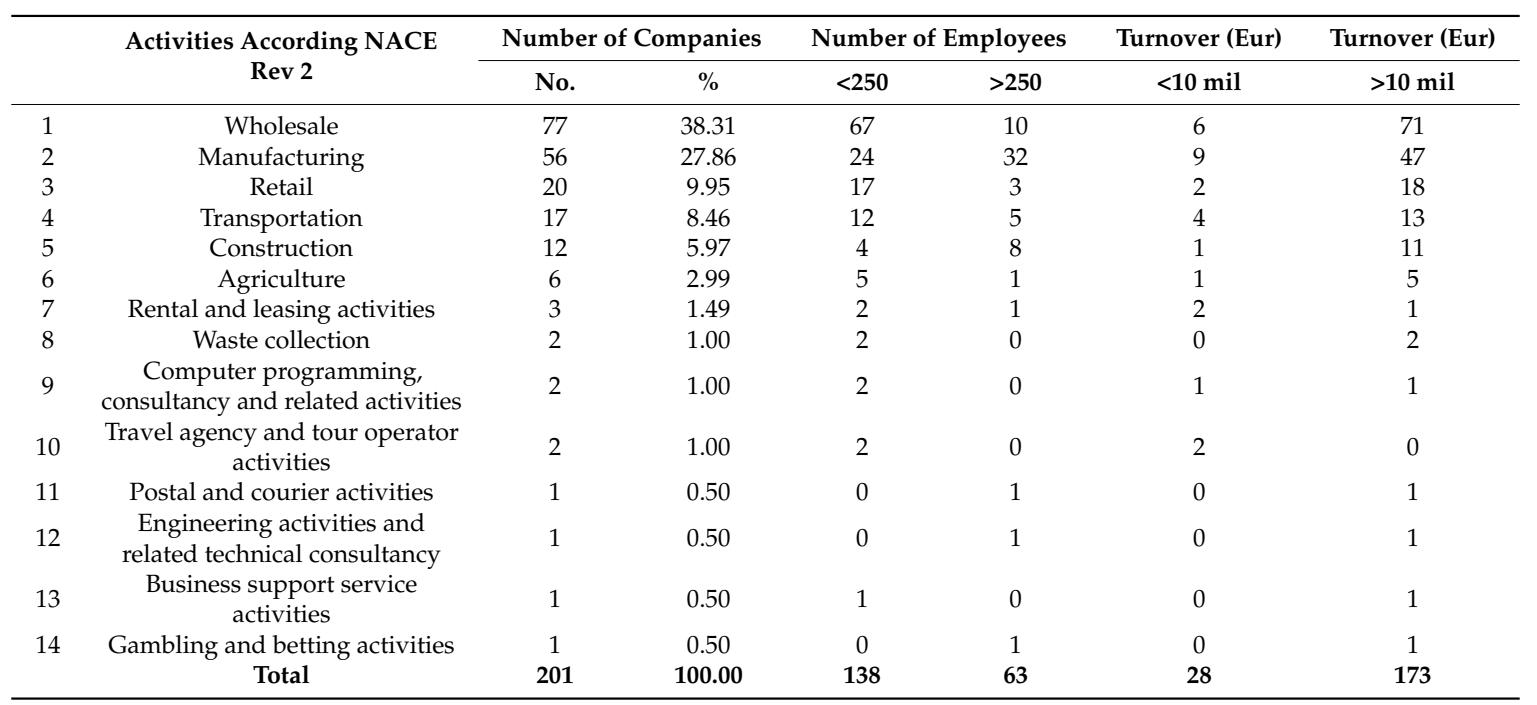

\section{Results and Discussion}

Following the sequence of research questions mentioned above, results of our research are in the following sub-sections. 


\subsection{Characteristics of the Romanian Family Businesses}

Historically speaking, family businesses in Romania have been affected by the change of the political regime after World War II, respectively the instauration of communism. 29 years after switching to a market economy, family businesses represent a large segment of private companies, that is, $65 \%$ according to Mandl's report [22].

At the end of December 2018, there were over 927,000 active companies, owned by individuals, the average number of associates being 1.47. Unfortunately, the data provided by the National Trade Register Office does not include data regarding the associates' kinship, but considering that the average number of associates is below 2, we could consider that at least $65 \%$ are family businesses (having one or more associates from the same family). From Table 3 we can notice that most of the associates who own these companies (55.48\%) are between 30 and 49 years of age. Also, we observed that $35.36 \%$ of the associates are over 50 years of age, which indicates the fact that this group has reached the moment when it can involve their successors in their business, or can own and manage the business together.

Table 3. Distribution of associates/shareholders by age.

\begin{tabular}{ccc}
\hline The Age of the Associates/Shareholders & Number & Percentage \\
\hline Up to 29 years & 124,502 & $9.16 \%$ \\
30-39 years & 361,246 & $26.58 \%$ \\
40-49 years & 392,880 & $28.90 \%$ \\
50-59 years & 257,898 & $18.97 \%$ \\
over 60 years & 222,836 & $16.39 \%$ \\
\hline Number of active companies owned by individuals & $\mathbf{1 , 3 5 9 , 3 6 2}$ & $\mathbf{1 0 0 \%}$ \\
\hline Average number of associates & $\mathbf{1 . 4 7}$ \\
\hline
\end{tabular}

Source: own processing from the National Trade Register Office website [86].

In the European Union, family businesses represent over $60 \%$ of the total of companies, according to statistics published on their own website [87]. The present statistics do not reflect the importance and impact of family businesses across Europe and there are discussions concerning the separate reporting of these businesses by the Eurostat, the European Union's statistics bureau, and also in national statistics. Thus, the European Commission launched a project, Statistics for Family Businesses, whose objective is "the collection of the data in the area of family businesses".

Romanian family businesses have similar characteristics to those from the European Union, especially with those in Eastern Europe, but also significant differences generated by the internal environment. Considering the short period of time elapsed from the establishment of these family businesses, we can assert that they do not have yet a solid tradition, but continue to develop and keep up with challenges which may appear. More attention with regard to the study of the Romanian family businesses is currently made by the biggest professional services companies (PwC, Ernst \& Young, and KPMG), whose results we will analyze next. From the surveys conducted by the abovementioned companies, we have extracted the following characteristics of the Romanian family businesses: governance and succession planning.

\subsubsection{Governance in Family Business}

Most family businesses in Romania have a subsistence character, which allows them to ensure a certain standard of living only for their owner and his/her family [88]. Not all family businesses have implemented work procedures or corporative governance mechanisms. Unlike corporations, which have very well established protection mechanisms, the family businesses are much more vulnerable when it comes to crises that may occur inside the family. 
Thus, we noted that only $33 \%$ of family businesses have formal governance mechanisms, compared to $88 \%$ at the EU level and over $90 \%$ at global level (Figure 2). The most common governance mechanism of the Romanian family businesses is represented by the shareholder agreement, similar with the EU and globally.

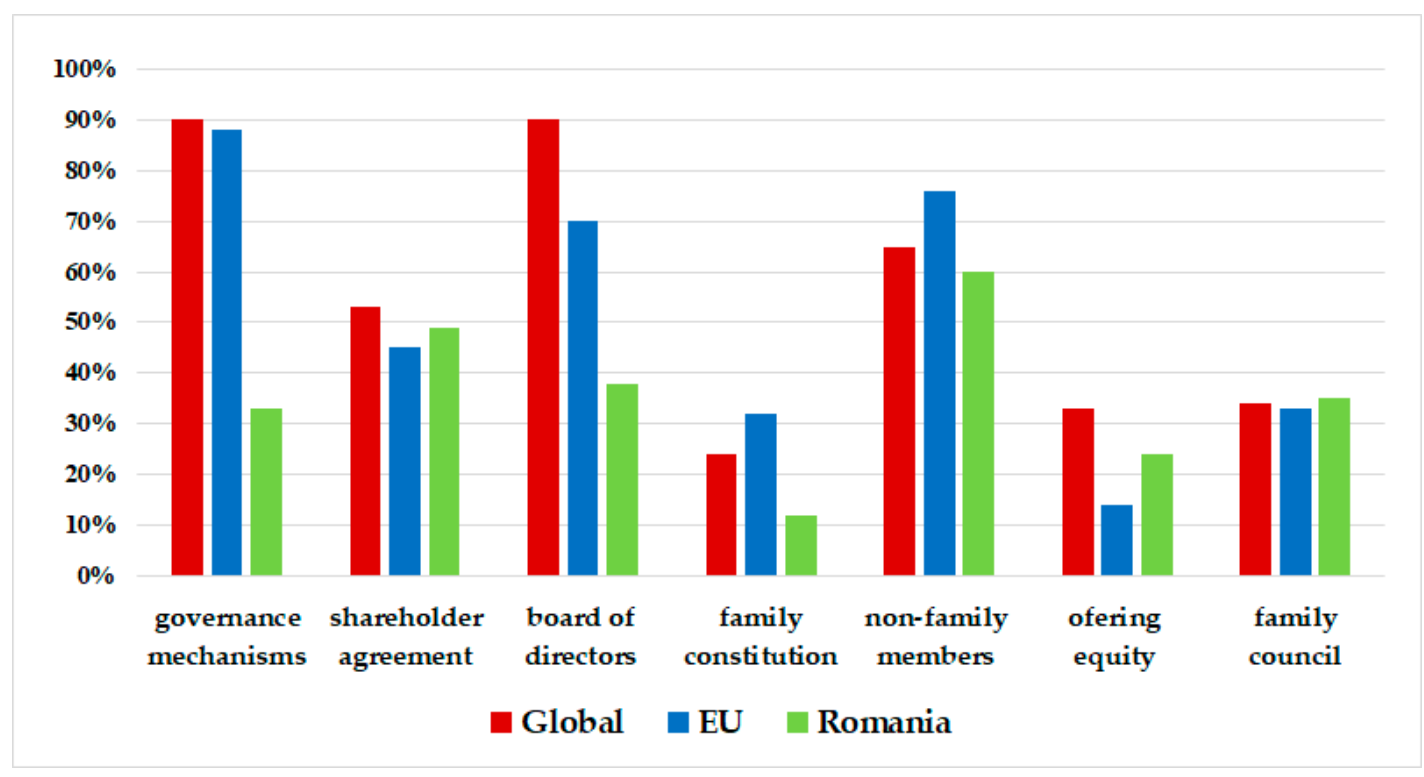

Figure 2. Governance characteristics within family businesses.

Another indicator of governance is the existence of a board of directors. Only $38 \%$ of the Romanian family businesses have a board of directors, compared to $70 \%$ in the EU, and $90 \%$ globally. It is worth mentioning that one quarter of the Romanian family business representatives expressed their intention to establish a board of directors in the next 2 or 3 years. They have admitted that a strong board of directors could reduce the number of internal conflicts, and would contribute to the succession planning.

The family constitution is another mechanism of governance that has been adopted in Romania, but only by $12 \%$ of the family businesses, compared to $32 \%$ at the EU level, and $124 \%$ globally.

The management of the family businesses can be performed by family members or non-family members. In Romania, over a third of the board of directors' members are exclusively from the family, compared to $24 \%$ at EU level, and $34 \%$ at the global level. Therefore, the difference is represented by non-family members' management, who can also be rewarded by offering equity in the company. Thereby, $24 \%$ of the Romanian family businesses offer shares, compared to $14 \%$ in the EU, and $33 \%$ at a global level.

Another characteristic of family business governance is represented by the existence of the family council which manages the family wealth, creates the politics and establishes the business strategy. In Romania, over a third of the family businesses have created a family council, comparable with EU and global level.

\subsubsection{Succession Planning}

The transfer of family businesses to the next generation represents the warranty of business continuity. An interesting comparison between Romania and other countries arises in respect to the succession planning, as shown in Figure 3. 


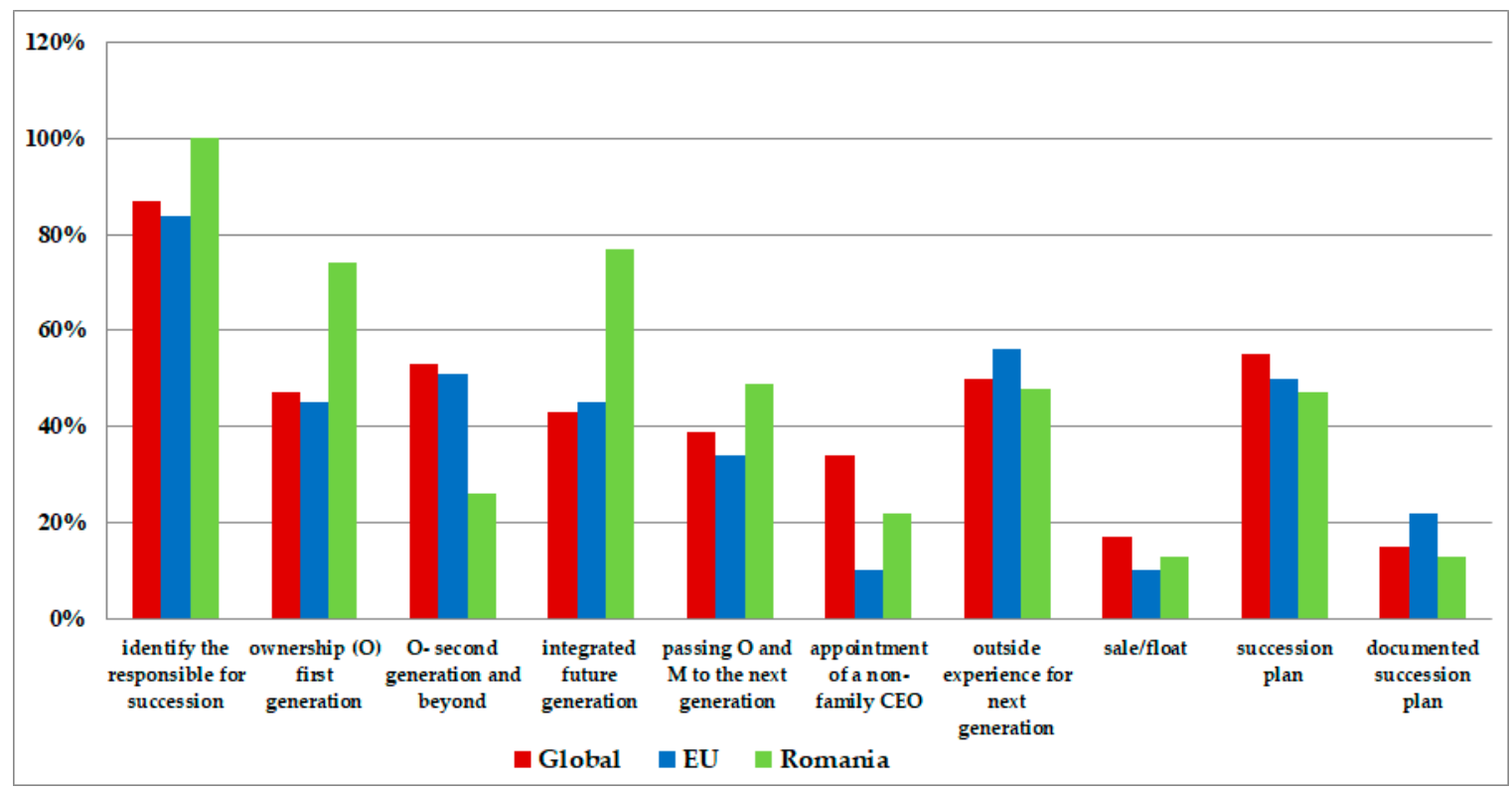

Figure 3. Succession planning.

An important aspect of succession planning is identifying the person responsible for the succession. Therefore, in Romania, all those who were interviewed have identified the responsible persons, compared to $84 \%$ in the EU, and $87 \%$ globally. They indicated the business owners in the first place with $78 \%$, compared to the global level where they are second, with $20 \%$. Globally, the biggest responsibility is held by the board of directors with $44 \%$, compared to $5 \%$ in Romania.

As we mentioned earlier, Romanian family businesses are relatively young, but some have reached the time for generational change. In this context, $74 \%$ of businesses are facing the first generation, compared to the $45 \%$ in the EU and the $47 \%$ globally. The share arising from the analyzed surveys is quite similar to the official national statistics presented, were we noted that $65.22 \%$ of the associates are under the age of 50 years, the threshold we consider for a generation change.

An important phase in transferring the business to the new generation is represented by the integration of the future generation of family members into the management. In this case, in Romania, the percentage of the new generation involvement in managing the business is $77 \%$, higher than at $\mathrm{EU}$ level (45\%) or global (43\%) level. Also, the Romanian family businesses record a higher percentage of passing the ownership and the management of the business to the next generation, that is, $49 \%$, compared to $34 \%$ in the EU and 39\% globally. The appointment of a non-family CEO, retaining ownership within the family in Romania is noted in $22 \%$ of cases, compared to $10 \%$ in EU, and $34 \%$ globally.

In order to employ the young generation in the family business, it is necessary to gain experience outside of the family company. In Romania, $48 \%$ of the companies consider that $3-5$ year of prior experience is required, compared to $56 \%$ at EU level where experience is required, without mentioning a minimum period of time, and globally, where 3 years of experience is considered to be needed. The term of experience requires in the first place the knowledge of business ethics (63\% in Romania and $59 \%$ globally).

Considering a rather nationalistic character of the Romanian family businesses, only $13 \%$ of their representatives have the intention to sell or to publicly list their business, compared with $10 \%$ in the EU and $17 \%$ globally.

The Romanian family businesses depend on their founders, who are also managers in most of the cases, thus only a small share have thought about a succession plan, that is, $47 \%$, compared to $50 \%$ at EU and 55\% at global level. From these, only $13 \%$ have a discussed and documented succession plan, compared to $22 \%$ at EU level, and $15 \%$ at global level. 


\subsection{Result of Regression Analysis}

The empirical research began with descriptive statistics of all the studied variables and testing them for stationarity, which is presented in Table 4.

Table 4. Descriptive statistics.

\begin{tabular}{ccccccc}
\hline Variable & Obs. & Mean & Std. Dev. & Min & Max & HT Unit Root Test (z) \\
\hline Ownership & 1206 & 0.968 & 0.097 & 0.4 & 1 & $-19.198^{* * *}$ \\
Governance & 1206 & 0.939 & 0.199 & 0 & 1 & $-4.499^{* * *}$ \\
Management & 1206 & 0.856 & 0.268 & 0 & 1 & $-23.772^{* * *}$ \\
Succession & 1206 & 0.345 & 0.475 & 0 & 1 & $-4.984^{* * *}$ \\
ROA & 1206 & 0.095 & 0.077 & -0.099 & 0.549 & $-8.913^{* * *}$ \\
ROE & 1206 & 0.226 & 0.225 & -0.399 & 2.784 & $-10.248^{* * *}$ \\
PM & 1206 & 0.055 & 0.064 & -0.566 & 0.531 & $-18.666^{* * *}$ \\
TAT & 1206 & 2.267 & 1.635 & 0.088 & 11.204 & $-4.207^{* * *}$ \\
SR & 1206 & 0.898 & 0.301 & 0 & 1 & $-18.398^{* * *}$ \\
Debt ratio & 1206 & 0.495 & 0.218 & 0.027 & 0.974 & $-4.260^{* * *}$ \\
Age & 1206 & 20.549 & 3.280 & 2 & 27 & $-1.794^{* *}$ \\
Size & 1206 & 17.493 & 1.070 & 13.280 & 22.221 & $-3.942^{* * *}$ \\
Ind & 1206 & 38.164 & 16.743 & 1 & 32 & $-19.198^{* * *}$ \\
\hline
\end{tabular}

Source: own computation using Stata 13.

Of the independent variables, the ownership shows that family members hold $96.8 \%$ on average, from a minimum of $40 \%$ registered by a company from the manufacturing of fabricated metal products sector, to $100 \%$ in most companies. Involvement of family members in governance also has a high share of $93.9 \%$, with 5 companies $(2.48 \%)$ with only non-family members and 180 companies $(89.55 \%)$ in which governance is provided only by family members. Regarding participation of family in management, the average is $85.6 \%$ lower than the other indicators; 5 companies $(2.48 \%)$ having non-family managers and 152 companies $(75.62 \%)$ only having family managers. Thus, it can be seen that the involvement of non-family members is higher in business management, in line with the results of previous studies [73-75]. In our sample, $34.5 \%$ of companies have next generation members in at least one of the characteristics of family business: ownership, governance, management.

Of the dependent variables, the ones calculated on the basis of profit have negative values, which mean that in the sample there are companies that registered losses in at least one year during the analyzed period, in total there are 6 observations.

ROA was on average $9.5 \%$, from a minimum of $-9.9 \%$ registered by a computer programming company to a maximum of $54.9 \%$ of a company in the transportation sector. ROE was an average of $22.6 \%$ from a minimum of $-39.9 \%$ registered by a company from the manufacturing of industrial products sector to a maximum of $278.41 \%$ of a company in the manufacturing of textiles sector. PM was on average $5.5 \%$ from a minimum of $-56.6 \%$ registered by a computer programming company to a maximum of $53.1 \%$ of a company in the renting sector. And TAT, which expresses how many rotations of total assets are needed to obtain turnover, registered an average value of $226.7 \%$ with a minimum of $8.8 \%$ of the same company in the renting sector and a maximum of $1120.4 \%$ of a company in the wholesale food sector.

From official data, $89.8 \%$ of companies from the sample studied were involved in social responsibility activities, the main activity being charitable contributions, which has also a fiscal advantage.

Regarding the control variables, the age of companies is on average 20.54 years, the oldest companies being established in 1991 and the newest in 2010. The companies analyzed are covered by 32 activity codes on 2 digits by NACE Rev. 2. Other financial ratios have values that lie in between the minimum and maximum intervals. The size of the companies represents the total assets expressed in natural logarithm, in absolute value the highest value of assets was recorded by a company in the retail sale of other household equipment in specialized stores sector and the lowest was recorded by a 
company in the retail sale of food. The debt ratio is approximately $49.5 \%$ from a minimum of $2.7 \%$ of a company in the renting sector to a maximum of $97.4 \%$ of a company in the retail of pharmaceutical products sector.

The correlations between the variables are presented in Table 5. From all the characteristics of the family businesses, governance and management influenced most the financial indicators. There was a positive significant relationship with TAT (for both of them), ROA (for governance) and ROE (for management) and a negative one with PM (for both of them). Succession was found to have a direct influence on PM and an indirect correlation with TAT, and ownership registered a statistically significant correlation only with PM.

The results of the pre-estimation tests are presented in Table 6. We don't have a multicoliniarity problem since the VIF was 1.15, lower than 7, and the null hypothesis of constant variance was rejected for all models ( $p$-value is lower than 0.05). Regarding the Hausman test, we reject the null hypothesis at $1 \%$ significance level; Pesaran's test showed that we had cross sectional dependence in all the models $(\mathrm{Pr}=0.0000)$ and for the Wooldridge test we accept the alternative hypothesis that there was first-order autocorrelation ( $p$-value $<0.05)$.

In the following tables can be observed the results of the regressions, all were statistically significant, the values obtained for Wald chi 2 were bigger than the threshold at $1 \%$ level of confidence.

In Table 7 are presented the results of the regression models that consider ROA and ROE as the dependent variables. All the independent variables could influence ROA in a proportion of $62 \%$ which indicates a moderate correlation. Taking into account all the independent variables, we observe that ownership $(\mathrm{O})$ had the bigger influence. The same result was obtained when we analyzed the variables one by one. The influence of the family business characteristics on ROE is moderated; R-squared was 0.48 , which means that all variables could influence the dependent one in a proportion of $48 \%$, and the only variable statistically significant was governance $(G)$, both in the model with all characteristics and in the ones with only one.

Table 8 show the results of the regressions when PM and TAT are the dependent variables. The influence of the independent variables on PM is weak, all the variables could influence it in a proportion of $37 \%$ and only ownership and succession were statistically significant. Regarding TAT, the correlation with all the independent variables was a strong one, its dynamics could be explained by the influence of them in a proportion of $72 \%$. Ownership is the variable that most affected the equity ratio of the company. 
Table 5. The correlation matrix.

\begin{tabular}{|c|c|c|c|c|c|c|c|c|c|c|c|c|c|c|}
\hline & & 1 & 2 & 3 & 4 & 5 & 6 & 7 & 8 & 9 & 10 & 11 & 12 & 13 \\
\hline 1 & $\mathrm{O}$ & 1 & & & & & & & & & & & & \\
\hline 2 & G & $0.120 * * *$ & 1 & & & & & & & & & & & \\
\hline 3 & M & 0.020 & $0.364^{* * *}$ & 1 & & & & & & & & & & \\
\hline 4 & $\mathrm{~S}$ & 0.002 & -0.049 * & 0.050 * & 1 & & & & & & & & & \\
\hline 5 & ROA & -0.025 & $0.054 *$ & 0.019 & 0.005 & 1 & & & & & & & & \\
\hline 6 & $\mathrm{ROE}$ & -0.010 & 0.016 & $0.047^{*}$ & -0.013 & $0.597^{* * *}$ & 1 & & & & & & & \\
\hline 7 & PM & $-0.069^{* *}$ & $-0.128^{* * *}$ & $-0.144^{* * *}$ & 0.053 * & $0.526^{* * *}$ & $0.285^{* * *}$ & 1 & & & & & & \\
\hline 8 & TAT & 0.046 & 0.050 * & $0.182^{* * *}$ & $-0.127^{* * *}$ & $0.225^{* * *}$ & $0.233^{* * *}$ & $-0.299 * * *$ & 1 & & & & & \\
\hline 9 & CSR & $-0.098^{* * *}$ & 0.022 & -0.042 & $0.082^{* * *}$ & $0.074^{* * *}$ & -0.040 & $0.123^{* * *}$ & $-0.073^{* *}$ & 1 & & & & \\
\hline 10 & $\mathrm{DR}$ & $0.099 * * *$ & -0.013 & $0.108^{* * *}$ & -0.015 & $-0.302^{* * *}$ & $0.292^{* * *}$ & $-0.302^{* * *}$ & $0.155^{* * *}$ & $-0.096^{* * *}$ & 1 & & & \\
\hline 11 & Age & -0.005 & 0.019 & 0.004 & 0.045 & $0.125^{* * *}$ & $-0.070 * *$ & 0.016 & 0.050 * & $0.069 * *$ & $-0.191^{* * *}$ & 1 & & \\
\hline 12 & Size & 0.026 & $-0.256^{* * *}$ & $-0.403^{* * *}$ & $0.050 *$ & $-0.142^{* * *}$ & $-0.194^{* * *}$ & $0.183^{* * *}$ & $-0.490 * * *$ & $0.184^{* * *}$ & $-0.138^{* * *}$ & $0.089^{* * *}$ & 1 & \\
\hline 13 & Ind & -0.034 & $-0.076^{* * *}$ & -0.014 & $-0.163^{* * *}$ & -0.024 & 0.021 & -0.048 * & $0.164^{* * *}$ & -0.015 & $0.145^{* * *}$ & $-0.188^{* * *}$ & $-0.151 * * *$ & 1 \\
\hline
\end{tabular}

Note: ${ }^{*}, * *$ and ${ }^{* * *}$ represents the statistical significance at the level of $10 \%, 5 \%$, and $1 \%$.

Table 6. The results of the pre-estimation tests.

\begin{tabular}{|c|c|c|c|c|c|}
\hline & Mean VIF & Breusch-Pagan/Cook-Weisberg & Hausman Test & Pesaran's Test & Wooldridge Test \\
\hline DV:ROA & 1.15 & $\begin{array}{c}\text { Chi2 }(1)=126.29 \\
\text { Prob }>\text { chi2 }=0.0000\end{array}$ & $\begin{array}{c}\text { Chi2 }(6)=15.37 \\
\text { Prob }>\text { chi } 2=0.0176\end{array}$ & $\begin{array}{c}12.940 \\
\operatorname{Pr}=0.0000\end{array}$ & $\begin{array}{l}F(1200)=55.674 \\
\text { Prob }>F=0.0000\end{array}$ \\
\hline DV:ROE & 1.15 & $\begin{array}{c}\text { Chi2 }(1)=660.32 \\
\text { Prob }>\text { chi2 }=0.0000\end{array}$ & $\begin{array}{c}\text { Chi2 }(6)=17.97 \\
\text { Prob }>\text { chi } 2=0.0063\end{array}$ & $\begin{array}{c}10.888 \\
\operatorname{Pr}=0.0000\end{array}$ & $\begin{aligned} F(1200) & =9.009 \\
\text { Prob }>F & =0.0030\end{aligned}$ \\
\hline DV:PM & 1.15 & $\begin{array}{c}\text { Chi2 }(1)=310.30 \\
\text { Prob }>\text { chi2 }=0.0000\end{array}$ & $\begin{array}{c}\text { Chi2 }(3)=15.67 \\
\text { Prob }>\text { chi2 }=0.0157\end{array}$ & $\begin{array}{c}16.193 \\
\operatorname{Pr}=0.0000\end{array}$ & $\begin{array}{c}F(1.39)=29.281 \\
\text { Prob }>F=0.0000\end{array}$ \\
\hline DV:TAT & 1.15 & $\begin{array}{c}\text { Chi2 }(1)=224.33 \\
\text { Prob }>\text { chi2 }=0.0000\end{array}$ & $\begin{array}{c}\text { Chi } 2(3)=18.82 \\
\text { Prob }>\text { chi } 2=0.0045\end{array}$ & $\begin{array}{c}5.550 \\
\operatorname{Pr}=0.0000\end{array}$ & $\begin{array}{c}F(1.39)=63.222 \\
\text { Prob }>F=0.0000\end{array}$ \\
\hline DV:SR & 1.15 & $\begin{array}{c}\text { Chi2 }(1)=246.52 \\
\text { Prob }>\text { chi2 }=0.0000\end{array}$ & $\begin{array}{c}\text { Chi2 }(3)=3.72 \\
\text { Prob }>\text { chi } 2=0.7143\end{array}$ & $\begin{array}{c}162.471 \\
\operatorname{Pr}=0.0000\end{array}$ & $\begin{aligned} F(1.39) & =1.568 \\
\text { Prob }>F & =0.2120\end{aligned}$ \\
\hline
\end{tabular}

Source: own computation using Stata 13 
Table 7. The results of the regression models.

\begin{tabular}{|c|c|c|c|c|c|c|c|c|c|c|}
\hline & & & ROA & & & & & ROE & & \\
\hline O & $\begin{array}{c}0.0651 \\
(3.68)^{* * *}\end{array}$ & $\begin{array}{c}0.0954 \\
(5.19)^{* * *}\end{array}$ & & & & $\begin{array}{l}0.0217 \\
(0.47)\end{array}$ & $\begin{array}{l}0.0600 \\
(1.36)\end{array}$ & & & \\
\hline G & $\begin{array}{c}0.0309 \\
(3.56)^{* * *}\end{array}$ & & $\begin{array}{c}0.0485 \\
(5.30)^{* * *}\end{array}$ & & & $\begin{array}{c}0.0620 \\
(2.08)^{* * *}\end{array}$ & & $\begin{array}{c}0.0574 \\
(2.44)^{* *}\end{array}$ & & \\
\hline $\mathbf{M}$ & $\begin{array}{c}0.0149 \\
(2.09) * *\end{array}$ & & & $\begin{array}{c}0.0326 \\
(3.90)^{* * *}\end{array}$ & & $\begin{array}{c}-0.0160 \\
(-0.86)\end{array}$ & & & $\begin{array}{c}0.0088 \\
(0.51)\end{array}$ & \\
\hline $\mathrm{S}$ & $\begin{array}{c}0.0097 \\
(3.09)^{* * *}\end{array}$ & & & & $\begin{array}{c}0.0101 \\
(3.26)^{* * *}\end{array}$ & $\begin{array}{l}0.0071 \\
(0.43)\end{array}$ & & & & $\begin{array}{c}0.0072 \\
(0.40)\end{array}$ \\
\hline Debt ratio & $\begin{array}{c}-0.1094 \\
(-7.08)^{* * *}\end{array}$ & $\begin{array}{c}-0.1058 \\
(-6.67) * * *\end{array}$ & $\begin{array}{c}-0.1018 \\
(-6.61)^{* * *}\end{array}$ & $\begin{array}{c}-0.1037 \\
(-7.19)^{* * *}\end{array}$ & $\begin{array}{c}-0.0991 \\
(-6.66)^{* * *}\end{array}$ & $\begin{array}{c}0.3749 \\
(6.60) * * *\end{array}$ & $\begin{array}{c}0.3765 \\
(6.81)^{* * *}\end{array}$ & $\begin{array}{c}0.3747 \\
(6.97) * * *\end{array}$ & $\begin{array}{c}0.3816 \\
(7.04)^{* * *}\end{array}$ & $\begin{array}{c}0.3796 \\
(6.80)^{* * *}\end{array}$ \\
\hline Age & $\begin{array}{c}0.0030 \\
(4.73)^{* *}\end{array}$ & $\begin{array}{c}0.0034 \\
(4.58) * * *\end{array}$ & $\begin{array}{c}0.0033 \\
(4.45) * * *\end{array}$ & $\begin{array}{c}0.0034 \\
(4.36)^{* * *}\end{array}$ & $\begin{array}{c}0.0038 \\
(4.18)^{* * *}\end{array}$ & $\begin{array}{c}0.0036 \\
(1.17)\end{array}$ & $\begin{array}{l}0.0044 \\
(1.45)\end{array}$ & $\begin{array}{c}0.0035 \\
(1.16)\end{array}$ & $\begin{array}{l}0.0045 \\
(1.47)\end{array}$ & $\begin{array}{l}0.0046 \\
(1.51)\end{array}$ \\
\hline Size & $\begin{array}{l}-0.001 \\
(-1.48)\end{array}$ & $\begin{array}{c}-0.0014 \\
(-1.10)\end{array}$ & $\begin{array}{l}0.0011 \\
(0.90)\end{array}$ & $\begin{array}{c}0.0020 \\
(1.61)\end{array}$ & $\begin{array}{c}0.0027 \\
(2.15)^{* *}\end{array}$ & $\begin{array}{c}-0.0043 \\
(-0.88)\end{array}$ & $\begin{array}{l}-0.004 \\
(-0.84)\end{array}$ & $\begin{array}{c}-0.0033 \\
(-0.77)\end{array}$ & $\begin{array}{c}-0.0020 \\
(-0.46)\end{array}$ & $\begin{array}{c}-0.0019 \\
(-0.44)\end{array}$ \\
\hline Ind & $\begin{array}{l}0.0002 \\
(1.57)\end{array}$ & $\begin{array}{l}0.0002 \\
(1.43)\end{array}$ & $\begin{array}{c}0.0002 \\
(1.63)\end{array}$ & $\begin{array}{l}0.0003 \\
(1.74)\end{array}$ & $\begin{array}{c}0.0003 \\
(2.07)^{* *}\end{array}$ & $\begin{array}{c}-0.0005 \\
(-1.21)\end{array}$ & $\begin{array}{l}-0.0006 \\
(-1.38)\end{array}$ & $\begin{array}{l}-0.0005 \\
(-1.12)\end{array}$ & $\begin{array}{l}-0.0006 \\
(-1.29)\end{array}$ & $\begin{array}{c}-0.0005 \\
(-1.20)\end{array}$ \\
\hline Obs & 1206 & 1206 & 1206 & 1206 & 1206 & 1206 & 1206 & 1206 & 1206 & 1206 \\
\hline$R^{2}$ & 0.625 & 0.619 & 0.621 & 0.620 & 0.619 & 0.488 & 0.484 & 0.490 & 0.487 & 0.487 \\
\hline Wald chi2 & $2565.19^{* * *}$ & $543.54^{* * *}$ & $695.79 * * *$ & $713.5^{* * *}$ & $537.36^{* * *}$ & $1539.22 * * *$ & $471.97^{* * *}$ & $658.78^{* * *}$ & $703.47^{* * *}$ & $459.27^{* * *}$ \\
\hline
\end{tabular}

Table 8. The results of the regression models.

\begin{tabular}{|c|c|c|c|c|c|c|c|c|c|c|}
\hline \multirow[b]{2}{*}{$\mathbf{O}$} & \multicolumn{5}{|c|}{ PM } & \multicolumn{5}{|c|}{ TAT } \\
\hline & $\begin{array}{c}-0.0367 \\
(-2.56)^{* *}\end{array}$ & $\begin{array}{c}-0.0550 \\
(-4.26)^{* * *}\end{array}$ & & & & $\begin{array}{c}3.5704 \\
(6.46)^{* * *}\end{array}$ & $\begin{array}{c}4.3685 \\
(6.37)^{* * *}\end{array}$ & & & \\
\hline G & $\begin{array}{c}-0.0334 \\
(-1.56)\end{array}$ & & $\begin{array}{c}-0.0383 \\
(-3.82)^{* * *}\end{array}$ & & & $\begin{array}{l}0.1410 \\
(0.66)\end{array}$ & & $\begin{array}{c}1.5259 \\
(8.15)^{* * *}\end{array}$ & & \\
\hline M & $\begin{array}{l}0.0153 \\
(0.50)\end{array}$ & & & $\begin{array}{l}0.0025 \\
(0.09)\end{array}$ & & $\begin{array}{c}0.8513 \\
(3.48)^{* * *}\end{array}$ & & & $\begin{array}{c}1.2708 \\
(5.82)^{* * *}\end{array}$ & \\
\hline S & $\begin{array}{c}0.0145 \\
(7.10)^{* * *}\end{array}$ & & & & $\begin{array}{c}0.0142 \\
(6.80)^{* * *}\end{array}$ & $\begin{array}{c}-0.2745 \\
(-6.19) * * *\end{array}$ & & & & $\begin{array}{c}-0.2815 \\
(-7.03)^{* * *}\end{array}$ \\
\hline Debt ratio & $\begin{array}{c}-0.0550 \\
(-3.11)^{* * *}\end{array}$ & $\begin{array}{c}-0.0510 \\
(-2.19)^{* * *}\end{array}$ & $\begin{array}{l}-0.0538 \\
(-2.37)^{* *}\end{array}$ & $\begin{array}{c}-0.0597 \\
(-3.47)^{* * *}\end{array}$ & $\begin{array}{l}-0.0558 \\
(-2.37)^{* *}\end{array}$ & $\begin{array}{c}0.0930 \\
(0.31)\end{array}$ & $\begin{array}{l}0.1345 \\
(0.40)\end{array}$ & $\begin{array}{l}0.3421 \\
(0.95)\end{array}$ & $\begin{array}{l}0.2776 \\
(0.83)\end{array}$ & $\begin{array}{c}0.4079 \\
(1.07)\end{array}$ \\
\hline Age & $\begin{array}{c}-0.0006 \\
(-1.31)\end{array}$ & $\begin{array}{c}-0.0006 \\
(-1.24)\end{array}$ & $\begin{array}{c}-0.0004 \\
(-1.01)\end{array}$ & $\begin{array}{c}-0.0008 \\
(-1.36)\end{array}$ & $\begin{array}{l}-0.0009 \\
(-1.81)^{*}\end{array}$ & $\begin{array}{c}0.0875 \\
(4.40)^{* * *}\end{array}$ & $\begin{array}{c}0.0976 \\
(4.48)^{* * *}\end{array}$ & $\begin{array}{c}0.1042 \\
(4.55)^{* * *}\end{array}$ & $\begin{array}{c}0.09555 \\
(4.22)^{* * *}\end{array}$ & $\begin{array}{c}0.1135 \\
(4.34)^{* * *}\end{array}$ \\
\hline Size & $\begin{array}{c}0.0087 \\
(10.95)^{* * *}\end{array}$ & $\begin{array}{c}0.0090 \\
(11.40)^{* * *}\end{array}$ & $\begin{array}{c}0.0078 \\
(9.70)^{* * *}\end{array}$ & $\begin{array}{c}0.0062 \\
(5.38)^{* * *}\end{array}$ & $\begin{array}{c}0.0060 \\
(7.21)^{* * *}\end{array}$ & $\begin{array}{c}-0.2667 \\
(-13.77)^{* * *}\end{array}$ & $\begin{array}{c}-0.2863 \\
(-11.1)^{* * *}\end{array}$ & $\begin{array}{l}-0.1427 \\
(-5.7)^{* * *}\end{array}$ & $\begin{array}{c}-0.1070 \\
(-3.76)^{* * *}\end{array}$ & $\begin{array}{l}-0.0681 \\
(-1.85)^{*}\end{array}$ \\
\hline Ind & $\begin{array}{c}-0.0002 \\
(-0.89)\end{array}$ & $\begin{array}{c}-0.0003 \\
(-1.03)\end{array}$ & $\begin{array}{c}-0.0002 \\
(-1.14)\end{array}$ & $\begin{array}{c}-0.0003 \\
(-1.16)\end{array}$ & $\begin{array}{c}-0.0002 \\
(-0.88)\end{array}$ & $\begin{array}{c}0.0230 \\
(7.24)^{* * *}\end{array}$ & $\begin{array}{c}0.0256 \\
(8.10)^{* * *}\end{array}$ & $\begin{array}{c}0.0262 \\
(8.05)^{* * *}\end{array}$ & $\begin{array}{c}0.0247 \\
(7.63)^{* * *}\end{array}$ & $\begin{array}{c}0.0259 \\
(6.79)^{* * *}\end{array}$ \\
\hline Obs & 1206 & 1206 & 1206 & 1206 & 1206 & 1206 & 1206 & 1206 & 1206 & 1206 \\
\hline $\mathbf{R}^{2}$ & 0.3728 & 0.355 & 0.357 & 0.356 & 0.356 & 0.722 & 0.725 & 0.721 & 0.720 & 0.703 \\
\hline Wald chi2 & $1131.42 * * *$ & $551.18^{* * *}$ & $506.06^{* * *}$ & $881.63^{* * *}$ & $524.76^{* * *}$ & $6177.52 * * *$ & $4587.16^{* * *}$ & $862.32 * * *$ & $779.21 * * *$ & $488.44^{* * *}$ \\
\hline
\end{tabular}

Note: $z$-values are reported in parenthesis and ${ }^{*}, * *,{ }^{* * *}$ represents the statistical significance at the level of $10 \%, 5 \%$,

1\%; Source: own computation using Stata 13.

The research shows that family ownership, governance, management and succession all have a significant effect on companies' performance. The results answered our research questions and are based on the literature review.

Regarding the ownership, we received mixed results. A positive and significant correlation was obtained with ROA as the dependent variables $[89,90]$, which corresponds with the basic agency theory relating to owner-manager conflicts [32,33], also with TAT was a better correlation in line with similar research [89]. A negative significant correlation was obtained with PM and no correlation with ROE, according with results of Miller and LeBreton-Miller [29].

Another characteristic analyzed was governance, which had a positive and significant correlation with ROA, ROE and TAT (but only in the single factor model) and a negative correlation with PM (but only in the model without the other characteristics). The results show that this variable influenced the most the company performance, corresponding with the literature $[55,91]$.

According to agency theory, when ownership and management reside within a family, the companies' costs decrease. In this regard, we refer to Fama and Jensen [36] who state that "family members have advantages in monitoring and disciplining related decision agents". The results show that management has a positive and significant influence on ROA similar with the results obtained by Siddik and Allouche et al. [76,82] and TAT [89]. 
The results regarding the succession are heterogeneous; we found a positive and significant correlation with ROA and PM [89], a negative correlation with TAT and no correlation with ROE [29].

From all the financial indicators taken into analysis, TAT was most influenced by the family business characteristics, a moderate correlation was found with ROA and the weakest ones were with ROE and PM.

In Table 9 are presented the results of the regression model that considers the non-financial indicator social responsibility (SR), expressed by charitable contributions, as the dependent variable.

Table 9. The results of the regression models.

\begin{tabular}{|c|c|c|c|c|c|}
\hline \multirow[b]{2}{*}{$\mathbf{O}$} & \multicolumn{5}{|c|}{ SR } \\
\hline & $\begin{array}{l}-11.8053 \\
(-5.98)^{* * *}\end{array}$ & $\begin{array}{c}-9.6857 \\
(-5.86)^{* * *}\end{array}$ & & & \\
\hline G & $\begin{array}{c}1.4234 \\
(2.78)^{* * *}\end{array}$ & & $\begin{array}{c}0.0599 \\
(-3.82) * * *\end{array}$ & & \\
\hline $\mathbf{M}$ & $\begin{array}{c}0.1137 \\
(0.21)\end{array}$ & & & $\begin{array}{c}-0.4852 \\
(-1.08)\end{array}$ & \\
\hline$S$ & $\begin{array}{c}0.5933 \\
(2.72)^{* * *}\end{array}$ & & & & $\begin{array}{c}0.5746 \\
(2.66)^{* * * *}\end{array}$ \\
\hline Debt ratio & $\begin{array}{l}-1.0208 \\
(-1.76)^{*}\end{array}$ & $\begin{array}{c}-0.9444 \\
(-1.60)\end{array}$ & $\begin{array}{c}-1.6741 \\
(-2.93)^{* * *}\end{array}$ & $\begin{array}{c}-1.5589 \\
(-2.81)^{* * *}\end{array}$ & $\begin{array}{c}-1.6980 \\
(-2.92)^{* * *}\end{array}$ \\
\hline Age & $\begin{array}{l}0.0317 \\
(1.15)\end{array}$ & $\begin{array}{c}0.0417 \\
(1.52)\end{array}$ & $\begin{array}{c}-0.0043 \\
(-0.16)\end{array}$ & $\begin{array}{c}0.0029 \\
(0.11)\end{array}$ & $\begin{array}{c}-0.0047 \\
(-0.17)\end{array}$ \\
\hline Size & $\begin{array}{c}0.6789 \\
(7.15)^{* * *}\end{array}$ & $\begin{array}{c}0.6443 \\
(7.11)^{* * *}\end{array}$ & $\begin{array}{c}0.1833 \\
(3.86)^{* * * *}\end{array}$ & $\begin{array}{c}0.1976 \\
(4.51)^{* * * *}\end{array}$ & $\begin{array}{c}0.1726 \\
(4.31)^{* * *}\end{array}$ \\
\hline Ind & $\begin{array}{l}0.01166 \\
(1.86) *\end{array}$ & $\begin{array}{c}0.0079 \\
(1.21)\end{array}$ & $\begin{array}{c}-0.0015 \\
(-0.27)\end{array}$ & $\begin{array}{c}-0.0009 \\
(-0.15)\end{array}$ & $\begin{array}{c}0.0008 \\
(0.14)\end{array}$ \\
\hline Obs & 1206 & 1206 & 1206 & 1206 & 1206 \\
\hline Wald chi2 & $442.19^{* * *}$ & $445.86^{* * *}$ & $515.11^{* * *}$ & $505.03^{* * *}$ & $507.90^{* * *}$ \\
\hline
\end{tabular}

Note: $z$-values are reported in parenthesis and ${ }^{*},{ }^{* *},{ }^{* * *}$ represents the statistical significance at the level of $10 \%, 5 \%$, $1 \%$; Source: own computation using Stata 13 .

Taking into account social responsibility (SR) as the dependent variable, in Table 9 we can observe a negative correlation with ownership $(\mathrm{O})$, a positive one with succession $(\mathrm{S})$ and governance $(\mathrm{G})$ but only in multifactorial regression. No correlation was found between management $(\mathrm{M})$, family business characteristics and social responsibility. If the next generation is involved in at least one of ownership, governance or management, then the odds that company is socially responsible increase by 1.8 times.

\subsection{Discussion}

Based on the indicators analyzed, it was observed that the companies are not built with a corporatist structure and they are in the long term consolidation phase. The statistical results are in accordance with the studies conducted by consulting companies, which leads us to conclude that the sample is representative. Family businesses in Romania have the same characteristics as companies in Central and Eastern European countries, most of them have first-generation property and are in a process of business consolidation [67]. Based on the selection criteria, more companies could have been included in the sample, but some were sold by associates to multinationals, which is why the future of the family business depends on the conviction of family members to carry on the founders' dream, and this is based on the family's constitution.

The philosophy of family businesses is based on business going concern, with company mission and values that go beyond the initial purpose of a business to be profitable, based on relationships between family members. Most of the companies analyzed managed to exceed the activity threshold of 20 years, so one-third of them involved the successors.

The major involvement of family members in governance and management could be a positive factor because they have a direct interest for business development, but could also be a negative one, 
if they don't bring new ideas as could do the managers with specialized training to implement modern methods. That's why one of the factors stated in the consulting companies' studies was the training of the successors, or for them to have a minimum experience outside of the family company.

The involvement of the Romanian companies in social responsibility activities grew in the last years [92], one of the main reasons being the fiscal advantage. The most noticeable indicator is charitable contributions, which are given to various social actions, sports, culture and health. Therefore, the family businesses included in the sample engaged in this activity; the correlation between the family business characteristics and SR are in accordance with previous studies [68,69], but unexpectedly, the correlation of management with the SR was not identified, knowing that $\mathrm{M}$ is mandate to carry out the expenditure.

We consider that the purpose of the paper was accomplished, because the financial performance was highly correlated with all of the independent variables, a positive correlation with ROA according with Allouche et al. [82], a negative and no effect correlation with other three variables (ROE, PM and TAT) which are supported by previous research $[29,49,53]$. ROA was the indicator with significant influence, confirmed by an R-square of 0.625 , with a positive relationship with all of the indicators that reflect the characteristics of FB. The next relevant indicator that had an $R$-square of 0.722 was TAT, with a positive relationship with all indicators, except governance. ROE and PM registered a lower $R$-square of 0.488 and 0.3728 , which shows a week influence on all independent variables.

The results answered our research questions and are based on the literature review. Given the inexistence of official reports in Romania regarding family business, this research can be considered a beginning to deepen this field, which is widely debated in developed countries.

\section{Conclusions}

The present paper aimed to identify the characteristics of Romanian family businesses and to investigate if they act in a manner oriented towards sustainability and performance. In order to achieve these objectives, we performed qualitative research by analyzing the most recent surveys issued by large counseling companies regarding the family businesses topic, as well as by investigating the link between the ability of the Romanian family businesses to adapt to change or their behavior and their concerns regarding the development of family businesses.

Following our study, we have found that the Romanian family businesses record poorer governance structures than the family businesses from the EU and globally. Another different feature is the involvement of the new generation in the business management, which is much higher than in the EU and at a global level. Finally, we have noticed a conservative attitude regarding the intent on selling or listing the companies, which is significantly different to the EU or global one.

Regarding the challenges, we found that Romanian family businesses are ready to face the changes (influenced by internal and external factors), so they are in line with the global trends. The main actions we identified being the involvement of external management, recruiting talented employees and involving the new generation in business management. All these relate to human resources, whether owner or employee, as the family business's own intangible elements which could create value by itself.

There are two reasons why this paper is contributing to the literature. First, we provide an extensive analysis of the Romanian family businesses from a perspective oriented towards the potential of creating value, knowing that FB contributes greatly to economic growth [93] and that the promotion of entrepreneurship is increasing in developed and developing countries [94]. Our research can help the owners and managers of the companies to make a radiography of their companies, to establish what can be improved, which strategy must be implemented for long-term sustainability and how the implication in social activities can be a better option in competition with multinational companies. Secondly, the results could be extrapolated to other countries, especially to emerging ones, which face a similar state of art, because this paper offers insights into a quite new type of business in Romania. 
The paper has also its limits. The first one refers to the fact that we could not use the official statistics database. As we mentioned, the policy makers are working at a design of a database, but for now it is only a project. The fact that a lot of papers have approached the topic led to the need for creating this database. In the absence of an official database, we have faced the second limit of our paper, which refers to the use of surveys having their own sample, setting their own criteria, and approaching a different period of time, which might have led to differences. We have tried, as much as possible, to employ a compact approach and to analyze only the joint indicators.

Also, future research directions could be the expanding of the sample by further investigations and identifying other Romanian companies that can be considered family businesses, as well as analyzing other relevant indicators. Also, comparative studies on family businesses from different countries can be carried out.

Author Contributions: Conceptualization, C.-D.H., R.-I.C.-P. and V.-P.H.; Data curation, R.-I.C.-P.; Formal analysis, R.-I.C.-P; Investigation, C.-D.H.; Methodology, C.-D.H. and R.-I.C.-P.; Project administration, C.-D.H.; Resources, C.-D.H. and R.-I.C.-P.; Software, R.-I.C.-P.; Supervision, C.-D.H.; Validation, R.-I.C.-P.; Visualization, C.-D.H.; Writing-original draft, C.-D.H., R.-I.C.-P. and V.-P.H.; Writing-review \& editing, C.-D.H.

Funding: This research received no external funding.

Acknowledgments: The authors would like to thank PwC Romania, Timisoara Office for the kind advice and for clarification about family business methodology and data collection.

Conflicts of Interest: The authors declare no conflict of interest.

\section{References}

1. European Family Business. Available online: www.europeanfamilybusinesses.eu/family-businesses/factsfigures (accessed on 1 February 2019).

2. Koestenbaum, P. The Philosophic Consultant. Revolutionizing Organizations with Ideas; Jossey-Bass/Pfeiffer: San Francisco, CA, USA, 2003.

3. Hategan, V.P. Consilierea Filosofică: De la Practică la Profesie; Ars Docendi: Bucharest, Romania, 2018; ISBN 978-606-998-025-5.

4. Iglesias, M.V. Does a Family-First Philosophy Affect Family Business Profitability? An Analysis of Family Businesses in the Midwest. Open Access Theses. 2015. Available online: https://docs.lib.purdue.edu/cgi/ viewcontent.cgi? article $=1517 \&$ context=open_access_theses (accessed on 23 January 2019).

5. European Foundation for the Improvement of Living and Working Conditions. Family Businesses: Do They Perform Better? Literature Review by London Economics. 2011. Available online: https://londoneconomics.co.uk/wp-content/uploads/2011/09/101-Comparing-the-economicperformance-of-family-businesses-and-non-family-businesses.pdf (accessed on 23 January 2019).

6. Neubauer, F.; Lank, A. The Family Business: Its Governance for Sustainability; Routledge: New York, NY, USA, 1998; Chapter 6; pp. 133-166.

7. Harveston, P.D.; Davis, P.S.; Lyden, J.A. Succession planning in family business: The impact of owner gender. Fam. Bus. Rev. 1997, 10, 373-396. [CrossRef]

8. Collins, J.D.; Worthington, W.J.; Schoen, J.E. Family business CEO succession: Examining personal retirement expectations. J. Small Bus. Strategy 2016, 26, 51-70.

9. Miller, D.; Le Breton-Miller, I.; Scholnick, B. Stewardship vs. stagnation: An empirical comparison of small family and non-family businesses. J. Manag. Stud. 2008, 45, 51-78. [CrossRef]

10. Hall, A.; Nordqvist, M. Professional management in family businesses: Toward an extended understanding. Fam. Bus. Rev. 2008, 21, 51-69. [CrossRef]

11. Stewart, A.; Hitt, M.A. Why can't a family business be more like a nonfamily business? Fam. Bus. Rev. 2012, 25, 58-86. [CrossRef]

12. Rahman, H.; Galván, R.S.; Martínez, A.B. Impact of family business on economic development: A study of Spain's family-owned supermarkets. J. Bus. Manag. Sci. 2017, 5, 129-138. [CrossRef]

13. European Family Business-EFB \& Deutsche Bank Report on Family Businesses in Europe. 2018. Available online: http:/ / www.europeanfamilybusinesses.eu/uploads/Modules/Publications/efb-db-report.pdf (accessed on 12 January 2019). 
14. Family Business Network Romania. Available online: http://www.fbn-romania.ro/asociatia-fbn-romania / asociati-fbn-romania (accessed on 5 February 2019).

15. Ceptureanu, E.G. Innovation and Change Management in Romanian SMEs Family Business. In Proceedings of the International Management Conference, Faculty of Management, Academy of Economic Studies, Bucharest, Romania, 25-28 August 2015.

16. Fotea, I.; Fotea, S.; Vaduva, S.; Pop, I. Fostering entrepreneurial learning in family business through a community of practice approach-Case study of Romanian family business. Econ. Marche J. Appl. Econ. 2012, XXXI, 25-38.

17. Fotea, S.; Pop, N.A.; Fotea, I. Developing an Understanding of Romanian Consumers' Perception of Family Firms. In Proceedings of the ECMLG2017 13th European Conference on Management, Leadership and Governance: ECMLG 2017, London, UK, 11-12 December 2017.

18. Schank, M.-J.; Murgea, A.; Enache, C. Family ownership and firm performance: Romania versus Germany. Timis. J. Econ. Bus. 2017, 10, 169-186. [CrossRef]

19. Chua, J.H.; Chrisman, J.J.; Sharma, P. Defining the family business by behavior. Entrep. Theory Pract. 1999, 23, 19-39. [CrossRef]

20. Habbershon, T.G.; Williams, M.; Macmillan, I.C. A unified systems perspective of family firm performance. J. Bus. Ventur. 2003, 18, 451-465. [CrossRef]

21. Nicholson, N. Evolutionary psychology and family business: A new synthesis for theory, research, and practice. Fam. Bus. Rev. 2008, 21, 103-118. [CrossRef]

22. Mandl, I. Overview of Family Business Relevant Issues-Final Report, Austrian Institute for SME Research. 2008. Available online: https:/ / ec.europa.eu/growth/smes/promoting-entrepreneurship/we-work-for/ family-business/index_en.htm (accessed on 15 April 2018).

23. Romanian Government. Ordonanta de Urgenta nr. 44/.2008 Privind Desfasurarea Activitatilor economice de Catre Persoanele Fizice Autorizate, Intreprinderile Individuale si Intreprinderile Familiale. Monitorul Oficial nr. 328/2008. Available online: http:/ / www.onrc.ro/documente/legislatie/OUG_Nr_44_2008.pdf (accessed on 5 July 2018).

24. Shanker, M.C.; Astrachan, J.H. Myths and realities: Family businesses' contribution to the US economy-A framework for assessing family business statistics. Fam. Bus. Rev. 1996, 9, 107-123. [CrossRef]

25. Astrachan, J.H.; Klein, S.B.; Smyrnios, K.X. The F-PEC scale of family influence: A proposal for solving the family business definition problem. Fam. Bus. Rev. 2002, 15, 45-58. [CrossRef]

26. Plato, A.B. The Republic of Plato; Basic Books: New York, NY, USA, 1991.

27. Aristotle. Politics; Hackett: Indianapolis, IN, USA, 1998.

28. Rousseau, J.J.; May, G. The Social Contract: And, the First and Second Discourses; Yale University Press: New Haven, CT, USA, 2002.

29. Miller, D.; Le Breton-Miller, I. Family governance and firm performance: Agency, stewardship, and capabilities. Fam. Bus. Rev. 2006, 19, 73-87. [CrossRef]

30. Brenes, E.R.; Madrigal, K.; Requena, B. Corporate governance and family business performance. J. Bus. Res. 2011, 64, 280-285. [CrossRef]

31. Pindado, J.; Requejo, I. Family business performance from a Governance perspective: A review of empirical research. Int. J. Manag. Rev. 2015, 17, 279-311. [CrossRef]

32. Eisenhardt, K.M. Making fast strategic decisions in high-velocity environments. Acad. Manag. J. 1989, 32, 543-576.

33. Jensen, M.; Meckling, W. Theory of the firm: Managerial behavior, agency costs and ownership structure. J. Financ. Econ. 1976, 3, 305-360. [CrossRef]

34. Demsetz, H. Ownership, Control, and the Firm: The Organization of Economic Activity; Blackwell: New York, NY, USA, 1988; Volume 1.

35. Ang, J.S.; Cole, R.A.; Lin, J.W. Agency costs and ownership structure. J. Financ. 2000, 55, 81-106. [CrossRef]

36. Fama, E.F.; Jensen, M.C. Separation of ownership and control. J. Law Econ. 1983, 26, 301-325. [CrossRef]

37. Chang, H.J.; Lin, S.J.; Hou, J.J. An investigation of family business from the perspective of dynamic capabilities. J. Chin. Manag. Rev. 2014, 17. Available online: http://cmr.ba.ouhk.edu.hk/cmr/webjournal/ v17n1/CMR401E13.pdf. (accessed on 5 July 2018).

38. Donaldson, L.; Davis, J.H. Stewardship theory or agency theory: CEO governance and shareholder returns. Aust. J. Manag. 1991, 16, 49-64. [CrossRef] 
39. Davis, J.H.; Schoorman, F.D.; Donaldson, L. Toward a stewardship theory of management. Acad. Manag. Rev. 1997, 22, 20-47. [CrossRef]

40. Fox, M.; Hamilton, R. Ownership and diversification: Agency theory or stewardship theory. J. Manag. Stud. 1994, 31, 69-81. [CrossRef]

41. Hegel, G.W.F. Hegel: Elements of the Philosophy of Right; Cambridge University Press: Cambridge, UK, 1991.

42. Gomez-Mejia, L.R.; Takacs-Haynes, K.; Nunez-Nickel, M.; Jacobson, K.J.L.; Moyano-Fuentes, J. Socioemotional wealth and business risks in family controlled firms: Evidence from Spanish olive oil mills. Adm. Sci. Q. 2007, 52, 106-137. [CrossRef]

43. Berrone, P.; Cruz, C.; Gomez-Meija, L. Socioemotional wealth in family firms: Theoretical dimensions, assessment approaches, and agenda for future research. Fam. Bus. Rev. 2012, 25, 258-279. [CrossRef]

44. Gottardo, P.; Moisello, A.M. The impact of socioemotional wealth on family firms' financial performance. Probl. Perspect. Manag. 2015, 13, 67-77.

45. Gavana, G.; Gottardo, P.; Moisello, A.M. The effect of equity and bond issues on sustainability disclosure. Family vs non-family Italian firms. Soc. Responsib. J. 2017, 13, 126-142. [CrossRef]

46. Stafford, K.; Duncan, K.; Dane, S.; Winter, M. A research model of sustainable family businesses. Fam. Bus. Rev. 1999, 12, 197-208. [CrossRef]

47. Núñez-Cacho, P.; Molina-Moreno, V.; Corpas-Iglesias, F.A.; Cortés-García, F.J. Family businesses transitioning to a circular economy model: The case of "Mercadona". Sustainability 2018, 10, 538. [CrossRef]

48. Oudah, M.; Jabeen, F.; Dixon, C. Determinants linked to family business sustainability in the UAE: An AHP approach. Sustainability 2018, 10, 246. [CrossRef]

49. Le Breton-Miller, I.; Miller, D. Why do some family businesses out-compete? Governance, long-term orientations, and sustainable capacity. Entrep. Theory Pract. 2006, 30, 731-746. [CrossRef]

50. Rutherford, M.W.; Kuratko, D.F.; Holt, D.T. Examining the link between familiness and performance: Can the F-PEC untangle the family business theory jungle? Entrep. Theory Pract. 2008, 32, 1089-1109. [CrossRef]

51. Mazzi, C. Family business and financial performance: Current state of knowledge and future research challenges. J. Family Bus. Strategy 2011, 2, 166-181. [CrossRef]

52. Basco, R. Family Business in Emerging Markets. In The Oxford Handbook of Management in Emerging Markets; Oxford University Press: Oxford, UK, 2018; pp. 1-22.

53. Garcia-Castro, R.; Aguilera, R.V. Family involvement in business and financial performance: A set-theoretic cross-national inquiry. J. Fam. Bus. Strategy 2014, 5, 85-96. [CrossRef]

54. Block, J. Family management, family ownership, and downsizing: Evidence from S\&P 500 firms. Fam. Bus. Rev. 2010, 23, 109-130.

55. Anderson, R.C.; Reeb, D.M. Founding-family ownership and firm performance: Evidence from the S\&P 500. J. Financ. 2003, 58, 130-132.

56. Carney, M.; Gedajlovic, E. Corporate governance and firm capabilities: A comparison of managerial, alliance, and personal capitalisms. Asia Pac. J. Manag. 2001, 18, 335-354. [CrossRef]

57. Grosu, C.; Almasan, A. Management Control: Between Global Performance and Social Responsibility. In Proceedings of the 8th International Conference Accounting and Management Information Systems, The Bucharest University of Economic Studies AMIS 2013, Bucharest, Romania, 12-13 June 2013.

58. Barney, J.B. Firm resources and sustained competitive advantage. J. Manag. 1991, 17, 99-120. [CrossRef]

59. Chirico, F.; Bau, M. Is the family an 'asset' or 'liability' for firm performance? The moderating role of environmental dynamism. J. Small Bus. Manag. 2014, 52, 210-225. [CrossRef]

60. Maury, B. Family ownership and firm performance: Empirical evidence from Western European corporations. J. Corp. Financ. 2006, 12, 321-341. [CrossRef]

61. Barontini, R.; Caprio, L. The effect of family control on firm value and performance: Evidence from continental Europe. Eur. Financ. Manag. 2006, 12, 689-723. [CrossRef]

62. Sacristán-Navarro, M.; Gómez-Ansón, S.; Cabeza-García, L. Family ownership and control, the presence of other large shareholders, and firm performance: Further evidence. Fam. Bus. Rev. 2011, 24, 71-93. [CrossRef]

63. Sciascia, S.; Mazzola, P. Family involvement in ownership and management: Exploring nonlinear effects on performance. Fam. Bus. Rev. 2008, 21, 331-345. [CrossRef]

64. García-Ramos, R.; García-Olalla, M. Board characteristics and firm performance in public founder-and non-founder-led family businesses. J. Fam. Bus. Strategy 2011, 2, 220-231. [CrossRef] 
65. Miralles-Marcelo, J.L.; del Mar Miralles-Quirós, M.; Lisboa, I. The impact of family control on firm performance: Evidence from Portugal and Spain. J. Fam. Bus. Strategy 2014, 5, 156-168. [CrossRef]

66. Vieira, E.F.S. The effect on the performance of listed family and non-family firms. Manag. Financ. 2014, 40, 234-253.

67. Kowalewski, O.; Talavera, O.; Stetsyuk, I. Influence of family involvement in management and ownership on firm performance: Evidence from Poland. Fam. Bus. Rev. 2010, 23, 45-59. [CrossRef]

68. Preslmayer, C.; Kuttner, M.; Feldbauer-Durstmüller, B. Uncovering the research field of corporate social responsibility in family firms: A citation analysis. J. Fam. Bus. Manag. 2018, 8, 169-195. [CrossRef]

69. Van Gils, A.; Dibrell, C.; Neubaum, D.O.; Craig, J.B. Social issues in the family enterprise. Fam. Bus. Rev. 2014, 27, 193-205. [CrossRef]

70. Leotta, A.; Rizza, C.; Ruggeri, D. The role of management accounting in the construction of the new generation leadership in family firms: An Actor-Reality perspective. Proc. Pragmatic Constr. 2016, 6, $34-48$.

71. Bisogno, M.; Vaia, G. The role of management accounting in family business succession. Afr. J. Bus. Manag. 2017, 11, 619-629. [CrossRef]

72. Prencipe, A.; Bar-Yosef, S.; Dekker, H.C. Accounting research in family firms: Theoretical and empirical challenges. Eur. Account. Rev. 2014, 23, 361-385. [CrossRef]

73. Ernst \& Young. Barometrul Afacerilor de Familie din Romania. 2017. Available online: https:/ / eyromania. ro/wp-content/uploads/2017/07 / Barometrul-afacerilor-de-familie_Romania-2017_FINAL_pdf (accessed on 29 March 2018).

74. PricewaterhouseCoopers. PwC Global Family Business Survey 2016/2017. Afacerile de Familie din România Strategia Antreprenorială și Planificarea Succesiunii. Available online: https:/ /www.pwc.ro/en/ publications / fbs / afacerile-de-familie-din-romania-editia-2017.pdf (accessed on 9 June 2018).

75. KPMG. European Family Business Barometer, 6th ed. 2017. Available online: https://home.kpmg.com/ xx/en/home/insights/2017/11/european-family-business-barometer-confidence-in-unity-sixth-edition. html (accessed on 29 March 2018).

76. Siddik, M.; Kabiraj, S. Family-owned firms between agency conflicts and stewardship: Corporate governance factors driving firm performance. J. Bus. Manag. Res. 2016, 1, 33-47. [CrossRef]

77. Imbrescu, C.M. Specific aspects regarding the prevention of insolvency based on the financial and economic analysis. Lucrări Științifice Management Agricol 2014, 16, 26-33.

78. Hategan, C.D.; Sirghi, N.; Ioana, C.R. The Financial Indicators Influencing the Market Value of Romanian Listed Companies at the Regional Level. In Proceedings of the 26th International Scientific Conference on Economic and Social Development—“Building Resilient Society”, Zagreb, Croatia, 8-9 December 2017; pp. 160-171.

79. Liu, W.; Wei, Q.; Huang, S.-Q.; Tsai, S.-B. Doing good again? A multilevel institutional perspective on corporate environmental responsibility and philanthropic strategy. Int. J. Env. Res. Public Health 2017, 14, 1283. [CrossRef]

80. Weng, P.S.; Chen, W.Y. Doing good or choosing well? Corporate reputation, CEO reputation, and corporate financial performance. North Am. J. Econ. Financ. 2017, 39, 223-240.

81. Chrisman, J.J.; Chua, J.H.; Sharma, P. Trends and directions in the development of a strategic management theory of the family firm. Entrep. Theory Pract. 2005, 29, 555-575. [CrossRef]

82. Allouche, J.; Amann, B.; Jaussaud, J.; Kurashina, T. The impact of family control on the performance and financial characteristics of family versus nonfamily businesses in Japan: A matched-pair investigation. Fam. Bus. Rev. 2008, 21, 315-329. [CrossRef]

83. Dyer, W.G. Examining the 'family effect' on firm performance. Family Bus. Rev. 2006, 1994, $253-273$. [CrossRef]

84. Lemmon, M.L.; Roberts, M.R.; Zender, J.F. Back to the beginning: Persistence and the cross-section of corporate capital structure. J. Financ. 2008, 63, 1575-1608. [CrossRef]

85. Data Selection Report. Available online: www.listafirme.ro (accessed on 7 December 2018).

86. National Trade Register Office Romania. Statistics. Available online: http://www.onrc.ro/index.php/ro/ statistici?id=243 (accessed on 5 February 2019).

87. European Commission. Overview of Family-Business-Relevant Issues: Research, Networks, Policy Measures and Existing Studies. 2009. Available online: http:/ / ec.europa.eu/growth/smes/promotingentrepreneurship/we-work-for/family-business/index_en.htm. (accessed on 23 May 2018). 
88. Romanian Government-Hotararea nr. 859 Privind Aprobarea Strategiei Guvernamentale Pentru Dezvoltarea Sectorului Intreprinderilor Mici si Mijlocii si Imbunatatirea Mediului de Afaceri din Romania-Orizont 2020 (Governmental Strategy for the Development of SME Sector and Improving the Business Environment in Romania. Horison 2020). Available online: https:/ /static.anaf.ro/static/10/Anaf/ legislatie/HG_859_2014.pdf (accessed on 23 July 2018).

89. Lee, J. The effects of family ownership and management on firm performance. Adv. Manag. J. 2004, 69, 46-53.

90. Lee, J. Family firm performance: Further evidence. Fam. Bus. Rev. 2006, 19, 103-115. [CrossRef]

91. Madison, K.; Holt, D.T.; Kellermanns, F.W.; Ranft, A.L. Viewing family firm behavior and governance through the lens of agency and stewardship theories. Fam. Bus. Rev. 2016, 29, 65-93. [CrossRef]

92. CSR Media \& Ernst \& Young. Tendinte si Realitati CSR in Romania 2016. Available online: https:/ / www.stiri.ong/library/files/ey_studiu_tendin $\%$ C8\%9Be_\%C8\%99i_realit $\%$ C4\%83\%C8\% 9Bi_csr_\%C3\%AEn_rom\%C3\%A2nia\%E2\%80\%932016_ro.pdf (accessed on 23 January 2019).

93. Memili, E.; Fang, H.C.; Chrisman, J.J.; de Massis, A. The Impact of Small- and Medium-Sized Family Firms on Economic Growth. Small Bus. Econ. 2015, 45, 771-785. [CrossRef]

94. Audretsch, D.B.; Heger, D.; Veith, T. Infrastructure and entrepreneurship. Small Bus. Econ. 2015, 44, $219-230$. [CrossRef]

(C) 2019 by the authors. Licensee MDPI, Basel, Switzerland. This article is an open access article distributed under the terms and conditions of the Creative Commons Attribution (CC BY) license (http://creativecommons.org/licenses/by/4.0/). 